was no waning in the degree of immunity afforded by the vaccines. Taking all the vaccines together, the attack rates in 'home exposures' at six-monthly intervals after vaccination showed no evidence of increasing two and a half to three years after vaccination (Table VIII)." I know of no reliable figures, based on large numbers, where the observation of the vaccinated was continued for more than three years.

Medical Research Counerences

Medical Research Council, Brit. med. J., 1956, 2, 454

\section{Diagnosis of Whooping-cough}

Q.-What are the latest methods of diagnosing whoopingcough?

A.-The diagnosis of whooping-cough before the paroxysms or when these are atypical is best established by isolation of the Haemophilus pertussis on a cough plate or from a pernasal swab. If there is no spontaneous cough one should be elicited; a simple and infallible way of doing this is described in detail in the British Encyclopaedia of Medical Practice in the chapter on whooping-cough. In general practice a pernasal swab is preferable to a cough plate, but the swab must be taken immediately after a bout of coughing, passed along the floor of the nose straight back on the nasopharynx, and cultured the same day. The culture medium should contain $50 \%$ of fresh blood, half a unit of penicillin per millilitre, and should not be more than eight days old. A definite result can be obtained in four days and will be found positive in $95 \%$ of cases in the first and second weeks of the disease. The percentage of positive results diminishes rapidly in the third and fourth weeks, but the clinical diagnosis is usually obvious at this stage.

A total leucocyte count of over 20,000 cells, with $70 \%$ or more of lymphocytes, can help in confirming a suspected attack of whooping-cough, but by itself is not diagnostic. A high lymphocyte count may be seen in children with other infections, and it can follow the administration of pertussis vaccine. Though areas of pulmonary collapse are often a complication of whooping-cough, there is no diagnostic radiological picture. Enlarged hilar glands are not due to whooping-cough. Positive complement-fixation test and the presence of specific agglutinins occur too late in the disease to be of much practical value in diagnosis.

\section{REFERENCE}

1 Laurent, L. J. M. in British Encyclopaedia of Medical Practice, 1952, edited by Lord Horder, vol. 12, p. 693 . Butterworth. London.

\section{Pulsus Paradoxus}

Q.-What is the explanation of the phenomenon of pulsus paradoxus in constrictive pericarditis?

A.-When the diastolic filling of the heart is restricted by pericardial effusion or constriction of the pericardial sac, the pulse weakens on inspiration. As a result of the restricted inflow the output falls and a weak pulse is easily felt with the finger on inspiration.

\section{Ascorbic Acid Prophylaxis in Toxic Drug Therapy}

0. - It has been claimed ${ }^{1}$ that liberal dosage with ascorbic acid, together with small oral doses of a ferrous preparation to catalyse the redux activity of the vitamin, counteracts the harmful side-effects of phenylbutazone therapy. Can this claim be taken as settled?

A.-To settle a claim that a combination of ascorbic acid in large amount together with a ferrous preparation would counteract such effects of phenylbutazone as agranulocytosis and aplastic anaemia would obviously be a major scientific undertaking. There is evidence that ascorbic acid is of value in benzene poisoning, which is an industrial hazard, but there has been no formal investigation of its action in agranulocytosis. One serious difficulty is that there is no method of producing agranulocytosis experimentally which works in more than a proportion of animals.
Daft et al. ${ }^{2}$ produced granulocytopenia in rats by including $1 \%$ thiourea in the diet, and a test of the value of ascorbic acid could be made by using such animals. It is hard to suppose that conclusive evidence of the value of ascorbic acid could be obtained from patients. The evidence obtained by Drummond ${ }^{3}$ appears to be complicated by the administration of cortical hormones as well as ascorbic acid. In a later paper by Drummond and Atlas ${ }^{4}$ two further cases were described in which the leucopenia due to phenylbutazone was counteracted by giving doses of vitamin C such as $250 \mathrm{mg}$. twice daily and a ferrous iron preparation three times a day.

\section{REFERENCES}

2 Drummond, J., Brit. med. J., 1957, 2, 1546. exp. Bloi. Kornerg, A. 61.

exp. Blol., 1946, 61, 154. $1950,24,975$.

- Drummond Atlas, L., ibid., 1953, 27, 997.

\section{Infra-red Fire}

Q.-Is the use of an infra-red electric fire for heating $a$ room detrimental to health?

A.-No; an electric fire emits infra-red rays and some visible rays. The effect of the former is only to heat, and, provided ordinary precautions against burning are taken, there can be no possible detriment to health.

\section{NOTES AND COMMENTS}

"Wind."-Dr. J. A. RANKIN (Reading) writes : I was interested to read the answer on the above subject ("Any Questions?" June 28 , p. 1556). The gas content of the bowel is of interest to me in radiodiagnosis, and recently I carried out some investigations from this point of view. A series of patients was given a course of digestive enzyme therapy and their bowel gas content compared with that in a similar control series. The faecal residues were also sent for analysis. The results showed that the treated cases were much freer of bowel gas, and that digestion was more complete. It would appear, therefore, that it is possible to influence bowel gas formation by digestive enzyme therapy, at the same time improving digestive processes, and I feel sure that clinical investigation of such enzyme therapy would be most rewarding.

OUR EXPERT replies: It is not stated how the bowel gas content was measured. However, it is understood that $x$-ray films of the abdomen were clearer of gas shadows on this treatment than without it. Frankly, caution is needed in interpreting results in this type of work. It is difficult to understand how digestive enzymes could reduce bowel gas, for some gas is produced during digestion in the gut. In any case upwards of half the gas in the gut is swallowed nitrogen, and it is difficult to understand how this could be influenced in the way suggested.

Correction.-In the report of Professor G. W. A. Dick's remarks at the meeting of the Section of Medicine at Birmingham (Journal, July 26, p. 222) the words "some clinical infections" were printed instead of " subclinical infection."

Collected Articles from the "British Medical Journal "

The following books are available through booksellers or from the Publishing Manager, B.M.A. House. Prices, which include postage, are now the same for both inland and overseas. Emergencies in General Practice (26s. 9d.).

Refresher Course for General Practitioners, Volumes 2 and 3 (26s. 9d.).

Clinical Pathology in General Practice (22s. 3d.).

Any Questions?, Volumes 2 and 3 (8s. 3d. each).

All communications with regard to editorial business should be addressed All communications with regard to edict O THE EDITOR, BRITSB MEDICAL JOURNAL, B.M.A H99 TA SQUARE, LONDON, W.C.1. TELEPHONE: EUSTON 4499. Aitiology, Westcent, London. ORIGINAL ARTCLES AND the Brittsh forwarded for publcation are understood te stated

Medical Journal alone unTs the contrary stated.

Authors desiring REP.C.1, on receipt of proofs. Manazer, B.M.A. House These on MSS. if reprints are required, as Authors overseas should indica

proots are not sent abroad. Advertisement Director, W. 1 (hours 9 a.m. to B.M.A. House, Tavistock SUSTON 4499. TelEORAMS: Britmedads, We.m.). Then

Westcent, London. the The Association.

B.M A ScotTish OFrce: 7, Drumsheugh Gardens, Edinburgh. 